Names, Vol. 32, No. 2 (June 1984)

\title{
On the Right of Exclusive Possession of a Family Name*
}

\section{ROBERT M. RENNICK}

\section{Introduction}

$\mathrm{U}$ nder the common law, especially as interpreted by Thomas Falconer ${ }^{1}$ and James Manning, ${ }^{2}$ any person may freely attempt a change of name, though the new name becomes official only when other persons come to refer to the changer by it. Until others thus acknowledge the change, the person is still legally known by his original name. Even after the adopted name is recognized, however, as long as the original name is remembered, the bearer would do well to refer to himself by both names (i.e., "old name,", alias dictus "new name.") Eventually, when he comes to be known exclusively by his new name, it will have completely replaced his old name as a means of identifying him.

American (and I suspect English) name-changing practices today tend to overlook the distinction between the initiation of the change and its consummation. Such distinction is intended in the common law. Simply because a person has decided he would rather be Jones than Smith does not mean he has become Jones. Desire is but the first step; there is more to come. Manning outlined the steps in an effective change-of-name under the common law: After the desire comes the assumption of the new name. By bearing it and using it for a time, the individual publicizes it to others who eventually accept it and the fact of the change by addressing him by it, especially if they like him or owe him something or desire something from him. ${ }^{3}$ The "new" name becomes generally known and comes to identify him, though his former name may still be recalled on occasion, both names being thus associated with the same individual. Ultimately, the original name will be completely "abandoned and forgotten," replaced by the "new" name which alone identifies the person. This last

*Special acknowledgement is given to Professors Sol Jacobson and Leonard R. N. Ashley of Brooklyn College and the late Mr. Symington P. Landreth, attorney, of Philadelphia who critically read the manuscript and offered many suggestions and much encouragement. The final product, however, is solely the author's responsibility. 
stage will seldom, if ever, be reached in his lifetime though his descendants may be known by none other than the adopted name.

Judicial precedents supporting these statements can be found in Lord Tenterden's decision in Luscomb v. Yates:

A name assumed by the voluntary act of a young man at his outset into life, adopted by all who knew him, and by which he is constantly called, becomes, for all purposes which occur to my mind, as much and as effectively his as if he had an Act of Parliament to confer it upon him. ${ }^{4}$

The Act of Parliament or the Royal License for which some Englishmen apply in their efforts to secure a change-of-name, aside from being expensive, is really unnecessary. They are but formal alternatives to the common law procedure given above and have their only advantage in the fulfillment of the conditions of a will, as when one specifies that his property is to be bequeathed to another only in the event the latter adopts his name, and it is stipulated that this be done by Royal License or Act of Parliament. In that case, these alternative procedures must be followed.

The Acts of Parliament and the Royal License, however, do not do away with the common law requirement of usage and replacement. They do not make immediate the fact of the change as does similar formal machinery in the United States (i.e., the court authorization). The Act and License only permit and give notice of change. The change is not consummated until the individual takes advantage of the permit by publicly abandoning the use of his original name. ${ }^{5}$ At that point, however, he is binominous until such time as the original name has been completely forgotten.

There are extant no sets of laws universally respecting surnames in Great Britain, merely customary usage; no decrees dictate names to be borne or limitations to the act of name-changing. For the most part, this is the way it has always been. Excepted are a few isolated decrees enacted for the purpose of coping with crises in unsettled times and places, but so few as to show, in John Amphlett's words, how "unobtrusively custom has fulfilled its purposes." 6

Of limited coverage was an act passed in the fifth year of the reign of Edward IV requiring all Irishmen residing among Englishmen in the counties of Dublin, Myeth, Vriell, and Kildare to fully assimilate the ways of their English neighbors including, and especially by, the assumption of English surnames which would thenceforth be borne by all issue under pain of forfeiture of goods annually till the act be done. ${ }^{7}$

Another attempt to limit the free choice of names in Ireland came a century later when the use of the specific name, O'Neyle (O'Neill), was prohibited on the grounds that Ulstermen had deferred more to the sover- 
eignty of the O'Neills than to the English monarch; continued use of the name would constitute high treason against Her Majesty. ${ }^{8}$ Similarly, in 1600 , a law was enacted in Scotland proscribing the use of the name Ruthven. The law actually abolished that name, for its bearers had already committed treasonable acts against the Crown. ${ }^{9}$ Three years later the MacGregors were forced to abandon their name for the same reason. ${ }^{10}$

Twice again were restrictions placed on the free use of certain names. A section of the Aliens Restriction Act of 1919, which related to namechanging among aliens, barred such individuals from changing the names they had borne on August 4, 1914. This provision was derived from the wartime measure (c. 1915) proscribing the use by enemy aliens of any names but those by which they were called when the war began. ${ }^{11}$

The assumption of a surname is left to the discretion of the individual. In fact, it is merely by custom, with no explicit stipulation, that a child assumes the name of his father. He does so simply to establish and affirm his relationship with his sire and to show filial honor and respect. Surname perpetuation is for the sake of administrative convenience, to facilitate the identification of an individual and his kinship, and his differentiation from all others in the land.

One's name in English common law is merely that by which he is commonly known regardless of how he came by it. He can, with a few possible exceptions, take any name he wishes in place of any he previously possessed; and if he can convince others to accept him by his new name, it will become as truly his name as if he had borne it all his life. Furthermore, any man who contracts in any name may be sued in that name, even if his true name is something else, although, in practice, the title of the action will allege that the litigant is "also known as" his original name. Likewise, a sheriff would be justified in arresting a person whose name in the warrant is not that by which he is officially known, if by his adopted name he can also be recognized.

English common law also asserts that a person has no legal right to the exclusive use of any particular name. One is free to refer to himself by anyone else's name, except for the purpose of deliberately trading upon the other's name and reputation (i.e., to defraud the public into believing they are dealing with his namesake). However, there is always the risk of one's not being properly identified by others if he assumes a name with which they may be unfamiliar or which may be associated with another person. ${ }^{12}$

We have been dealing here exclusively with surnames. With perhaps slightly less assurance, we could have said the same about forenames. While English law used to be quite explicit about the preservation of Christian names, we find today that custom has created greater tolerance 
for the assumption of a forename different from that given at baptism. Though the Anglican tradition insists that such names be retained for the life of the individual (though until the seventeenth century they could be changed at the discretion of a bishop at the time of the child's confirmation, especially if the baptismal name failed to meet the standards of propriety and good taste of the time), this insistence has, of late, been tempered in practice; it is no longer strictly adhered to. Though one's true or legal name may still be his baptismal name, he may be known by another given appellation. ${ }^{13}$

In England, over the past century, both Christian name and surname were not infrequently changed together. Yet it is less common, at least among native Christian Englishmen, for the given name alone to be formally changed. More tolerant, still, are the English about non-Christian persons and immigrants changing their given names. The freedom to change a given name is more likely to be enjoyed in the United States. Here, inasmuch as "there is no union between Church and state and (thus) no obligation for parents to baptize their children," a given name in fact may be as freely changed as the family's name. ${ }^{14}$ This is especially done during naturalization proceedings.

\section{Right of Property In a Name}

From here on, we shall confine our remarks specifically to the issue of the right of property in a name as it is understood in the United States. This subject, however, is hardly a well-defined one. In American legal theory, as in English common law, the name is an individual's only in so far as he does something with it or in it. It represents its bearer; it identifies him to others. It is, in short, what he makes of it. But under the law, he has no exclusive right to it. Its only legal use is to identify him, though not to the point of distinguishing him completely from others. Any other person can freely and legally assume the name, provided its use by another involves no injury to the character, reputation, or property of a prior bearer and provided, further, that it does not have a fraudulent purpose. ${ }^{15}$

But how is such "injury to character, reputation, or property" to be determined? The issue may well involve a conflict of interests. When a person (or an organization) by the continued use of a particular name has established a reputation which is then associated with the name, and thus the name has come to have a distinct value to its bearer, he often feels that it ought, by right, be his alone, even to the point of excluding others from the use of a name to which they may have equal claim. ${ }^{16}$

If two persons have the identical name, and one, by his achievements, makes it so well known that it becomes clearly associated in the public eye 
with him, does the other have to give it up? Or, to put the issue another way, when one assumes the name of another does he really assume his identity? The obvious answer to this would be - only if he assumes, by the name, the relationship to another person or group or to his public which had already been that of the prior name bearer. ${ }^{17}$ This might be evidenced by the assumption of that person's occupation, for instance, from which perspective it could be hypothesized that there is a deliberate intention to deceive others into believing that they are dealing with the original name bearer.

This hypothesis does not always hold true, however; occupational similarity is not necessarily valid grounds for a judicial decision in favor of exclusive rights to a name as can be seen in the famous Samuel Goldwyn case. ${ }^{18}$

In 1916, Goldwyn, with two partners, Arch and Edgar Selwyn, established a motion picture producing company which they named The Goldwyn Pictures Corporation, a name derived from the combination of the first part of his name at that time, Goldfish, and the second part of theirs, Selwyn. ${ }^{19}$ Two years later, at the Selwyns' suggestion, Sam agreed to assume the name Goldwyn, in the interests of the corporation. According to the terms of the partnership, Goldwyn was to be the production head of the firm, and it was feared that the wartime antipathy toward things German in this country would handicap it in its appeals to the public if its executive should continue to bear so Germanic a name as Goldfish. Besides, Sam was already known by the firm's name and had, for two years, been receiving his mail addressed to that name. At first, Sam was not pleased with the idea of formally adopting the company's name, for it would mean "submerging (his own) identity in that of the corporation.", However, he was finally persuaded to make the change by the Selwyns' promise that he could continue using the Goldwyn name in the event he was no longer associated with the firm. Thus a court-authorized changeof-name went into effect in January, 1919.

Later that same year, the Goldwyn Pictures Corporation changed ownership; all assets including the name were transferred to a Delawarebased corporation. Sam stayed on as president of the new firm. By that time, the Goldwyn name had been registered as a trade mark at the United States Patent Office and had, the company believed, become its property. The name had become so thoroughly identified with the corporation and its film-making activities in the public mind that its use by any other corporation or person might conceivably, if not inevitably, lead to confusion. Moreover, in 1920, Sam had signed a contract which gave the corporation exclusive use of the Goldwyn name in film production activities. 
Two years later, Sam left the firm and began making films on his own with the advertising come-on: "Sam'l. Goldwyn Presents." In July of 1923, the corporation sent Sam a letter in which he was reminded of the 1920 contract, but Sam's answer was that, as far as he was concerned, the contract did not invalidate his right to use his name, Samuel Goldwyn, in connection with his own production of films. At that point, the corporation sought a court injunction to prevent Sam from ever using the name in any independent film-making ventures.

A compromise solution was reached in court on October 27, 1923 providing that Sam could continue using the name in showing and publicizing his films only if it were followed by the words "not now connected with Goldwyn Pictures Corporation" (a disclaimer phrase). Judge Learned Hand, who heard the case in the Federal District Court of the Southern District of New York, ruled that Goldwyn could not be deprived of a name that was clearly associated with him - one which he had made so memorable by his own achievements. On the other hand, the plaintiff firm could also not be denied the use of the Goldwyn name, but their exclusive use of the name as a trademark (which was at issue here) "was regarded as a violation of the rights of Mr. Goldwyn." In short, the right to use a name does not give exclusive right to it. ${ }^{20}$

The corporation appealed the decision and repeated its demands that Sam be restrained from ever using the Goldwyn name. Circuit Court of Appeals Judge Henry Wade Rogers, upholding the lower court's decision and confirming the compromise injunction, cited precedents in Hilton $v$. Hilton for "the right of a man to use his own name in his own business." 21 Sam had made it plain that it would be impossible for him to run his business in any other name as his films had always had, and would continue to receive, his personal attention. Furthermore, Justice Rogers pointed out, the compromise decision precluded the possibility of fraud, intentional or otherwise, in that the public, because of the addition of the disclaimer phrase, could hardly be led to confuse the two firms. The corporation's interests and property rights would thereby be protected.

Another case in which there was no evidence of deliberate intent on the part of a name-assumer to publicly trade on the name and reputation of the prior bearer was one which, in fact, led to the American prototype of legal decisions invalidating the right of exclusive possession of a name. In Olin v. Bate ${ }^{22}$ a Chicago physician named Henry Olin, a specialist in diseases of the eye and ear, had sued to prohibit one John Bate from continuing the use of the assumed name, Andrew G. Olin, in his own practice of medicine in the same city. According to Henry, Bate-Olin, who specialized in the treatment of venereal diseases, had advertised his practice in the mass media, and the consequent confusion of identity between the two 
physicians had led to an "injured reputation"' and loss of clientele to the complainant. In addition, Henry claimed, the advertising had deceived the public into believing that Bate-Olin was actually Henry and that, besides his more conventional medical practice, Henry was engaging in the "disreputable" one of treating "sexual diseases."

A second issue involved here was the prior admission to a medical school and the granting of a diploma to Bate-Olin on the condition that he give up his assumed name. Some five years before the present case had come to court, Henry had extracted an agreement from Bate, who was then, as later, known as Andrew G. Olin, that the latter, as an applicant to the medical school of which Henry was then a member of the faculty, would abandon his assumed name as a condition of his admission. In addition, if he were to promise to engage only in a "reputable" practice on graduation, he would have no difficulty in receiving his diploma. Bate apparently accepted these conditions, for he was admitted to the school and awarded his diploma therefrom. But he also established his practice in Chicago, and was determined to continue it, as Andrew G. Olin.

Bate, in turn, argued that he had never assumed the plaintiff's complete name, only his surname, which under the common law does not fully identify an individual as the one whose identity is in question. That is, the defendant had never referred to himself as Henry Olin; so there could be no confusion between the two. ${ }^{23}$ Moreover, he had taken his alias before coming to Chicago and before he had ever head of Henry Olin; in fact, he had borne the name, Olin, before even Henry had come to Chicago to establish his practice. Furthermore, they were really not in the same business in that their medical specialties were different.

In a verdict rendered by the Illinois State Supreme Court, to which lower and appellate court decisions had been appealed by Henry Olin, Justice John M. Scott declared for Bate-Olin by accepting and reiterating the arguments of the defendant. In addition, he ruled that the granting of (medical) diplomas ought not be made the subject of a bargain between students and faculty members for the personal advantage of the parties involved; so clearly this argument of the plaintiff was invalid. Justice Scott also ruled that there should not have been any confusion between the two Olins since anyone looking for an eye or ear specialist would hardly have been attracted by the advertisements of a specialist in veneral diseases. The few exceptions would hardly "amount to irreparable injury", to the complainant. Finally, since Bate had taken his name and settled in Chicago before Olin did, "whatever embarrassments to which he (Henry Olin) may be subjected, if any, had come to him from his own selection of a location in which to practice his own profession." 
Another case similar to those already presented and with a similar outcome was Baumann v. Baumann. ${ }^{24}$ This involved a suit by the first Mrs. Baumann to enjoin her husband's "second wife" from continuing to call herself Mrs. Charles L. Baumann and passing herself off as his wife after a court had nullified the husband's Mexican divorce from the plaintiff and his subsequent remarriage to the co-defendant. ${ }^{25}$ A New York appeals court, however, reversed the lower court's decision by pointing out that the defendants' behavior in "representing themselves as husband and wife," though "annoying and humiliating to the plaintiff" and even "socially and morally . . . reprehensible" in its own right, does not really justify giving the plaintiff exclusive right to the name. For one thing, there was no evidence that the second Mrs. Baumann was deliberately impersonating her predecessor, as an individual; that is, the codefendant did not claim to be the plaintiff, Berenice L. Baumann. Nor was any allegation made that the plaintiff had been or could be injured by a confusion in identity.

Of course, if one wished to split hairs, he could allege that an identityconfusion had existed in the matter of occupancy of a status position, that of Mr. Baumann's wife. On this issue the court pointed out that "the representation to the public that the co-defendant is the wife of . . the plaintiff's husband constitutes a breach of the plaintiff's marriage contract, (and) deprives the plaintiff of the exclusive right to be the only person having the legal right to be known as Mrs. Charles Ludwig Baumann . . .' But that was really beside the point. The plaintiff at that time was not living with Mr. Baumann, was receiving $\$ 21,000$ a year from him under a separation agreement, and was operating an independent business under the name Berenice L. Baumann; her business interests at least were not in jeopardy from the co-defendant's use of her husband's name.

The judgment of the lower court in nullifying the divorce and remarriage protected the plaintiff's marital status. Her relation to Mr. Baumann was still legally that of wife to husband; the defendant could not "come between them." In short, as the court pointed out, the behavior of the codefendant did "not constitute legal wrongs, which invade substantial legal rights of the plaintiff that can be ... protected by injunction." Unless the issue of property rights was involved, the court could not affirm the position of the plaintiff.

The very issue of name as indicative of status, however, was latched on to by the two dissenting justices in their support of the plaintiff's right to the exclusive possession of her husband's name. In spite of her independence from her husband, in that by their separation agreement she had 
relinquished the right of consortium and support, the plaintiff was still legally his wife and was publicly known in her community by that status. More than just her name was involved, but her position as Mrs. Baumann with its attendant relationship to her husband and the image this invoked to others. The minority opinions claimed that there is an exclusive right to a name if that name clearly identifies its bearer with respect to legally recognizable relationships to others. The plaintiff had an exclusive right to her name as indicative of a status of which she had exclusive occupancy, namely as Baumann's wife. The co-defendant, however, by the assumption of Baumann's name was clearly impersonating the plaintiff and allowing others to believe that she, rather than the plaintiff, was truly Baumann's wife. Dissenting Justice O'Brien said that the co-defendant had no more right to the identity as Baumann's wife by its title than she would have had to the identity, by title, of "governor of Connecticut"' or "commanding general of the Mexican Army." Thus the dissenting justices took exception to the majority decision that the legal wife of a man was not entitled to prevent another from using his name and thus assuming the wife's identity. Both of the dissenters also felt that a court of equity has the right, if not the obligation, to "protect" a wife's status and to make a usurper give up a "relationship she is falsely and fraudulently" assuming.

The three cases cited above all involved a question of identity confusion brought about by the similarity of occupations or other status designations. But a name bearer might be equally fearful of the threat to his individual identity when sharing a common name with a neighbor, or if an assumer of his name should also have adopted the same given name. In fact, in the latter case, the fear that the assumer has deliberately sought to trade upon the other's identity may have even greater validity.

A Philadelphia attorney, Thomas E. Frame, taking this position, sought to prevent two brothers, Joseph Nicholas Falcucci and Benjamin R. Falcucci, from adopting his own family name - that of Frame - and to prevent Benjamin specifically from also assuming his own first name Thomas. The attorney pointed out that (1) confusion between the two families would arise inasmuch as they resided only six blocks from each other and that the appellant's family had antedated the others' by some thirty years; (2) it would have been more logical for the changers to have adopted a name like Fall, Falcon, Falcutt, etc., which proceeded more directly from the original name; (3) Benjamin, who had chosen Thomas as his new given name, had sought to give up a name which was not at all difficult to spell or pronounce, as he alleged, and certainly not uncommon in this country. Moreover, Lawyer Frame questioned why Benjamin, a 
minor, should be given the right to assume a surname different from that of his parents when, to insure family stability, all members should at least share the same name. ${ }^{26}$

In his decision in this case, Chief Justice George W. Maxey of Pennsylvania's Supreme Court backed up the opinion originally given by Common Pleas Judge Crumlish that the fact that the changers were not lawyers, nor even their residential proximity, would hardly justify the assumption that confusion between them would inevitably arise. On the right of adoption of a surname different from that of his parents, Justice Maxey ruled that the minor, Benjamin, was, after all, over 18 years of age, apparently knew what he was doing, and had two adult brothers who had already changed their name to Frame, with another " about to do so now."

Besides, Section 4 of the Act of 1923, which the appellant cited as the basis of his objections to the change, does not prevent a child from changing his name though his father prefers to retain the original name; especially if, as in this case, the father had made the application on behalf of his son. Section 4, Justice Maxey pointed out, merely provides that a change in the parent's name automatically calls for a change in the name of his minor children.

On the issue of exclusive right to a name, Justice Maxey cited Lord Chelmsford's ruling, in Du Boulay v. Du Boulay, ${ }^{27}$ to the effect that the common law precludes the notion of property right in a name unless fraudulent motives underlie the change. Such motives, by implication, could be exemplified by the act of a physician who applied for a change of name to that of a prominent practitioner in his community: "When a petitioner for a change of name is a competitor of a highly successful person whose name he wishes to assume, there is a reasonable ground for suspicion that his motive in seeking a change of name is an unworthy one, and due regard for both the public interest and for the person whose name is coveted would constrain a court to deny his petition."

The court would act with equal vigor in turning down a request for a change of name which was bizarre, difficult to handle, or had an "offensive connotation." Similarly, an attempt to adopt some famous name, like the full name of the President of the United States, by a person "motivated solely by vanity" would be rejected because it was the view of the court that "names should not be changed for trivial or capricious or vainglorious reasons." In any case, the court saw itself in the role of insuring "common decency and fairness to all concerned." The court was satisfied that none of the above issues was involved in the present case. Frame was hardly a "famous name" in that community; there were a 
sufficient number of Frames in the Philadelphia area telephone directories (no fewer than forty listings) to obviate any fear that the assumers would succeed in trading on the identity of this particular family for their own personal advantage. ${ }^{28}$

The very dissimilarity of occupations may also be grounds for an objection to the assumption of one's family name. An individual's acquaintances might be led to assume that he has gone into another business if there suddenly appeared in the community another person with the same name, and this might prove especially embarrassing to the prior name bearer if that business is in any way regarded as unrespectable.

In 1938, for example, a tavern owner named Harold Verne Useldinger requested a San Francisco Superior Court to allow him to formally adopt the name James J. Britt, which he had borne and been known by for some fourteen years. His application was denied, however, after an appearance by James Edward britt, a former boxer and sometime plumber, who called the court's attention to the several occasions in which friends had asked whether he had gone into the tavern business as they had seen his name on a large banner prominently displayed on the window of a local tavern which had recently changed management.

On appeal, however, the local court's decision was overruled. As the petitioner had been known by his adopted name for fourteen years and its assumption was regarded as a common law right, and since neither party was in the same business and thus neither fraud nor unfair competition was involved, there was no reason why the request for a formal change should have been denied. Such a formality merely makes "a matter of record" what had been a legal action in fact. In this decision, Justice Homer Spence of the First District Court of Appeals of the State of California (Division Two) penned the oft-quoted dictum that, "until the common law right to change one's name is abrogated by statute, courts should encourage rather than discourage the filing of petitions for change of name to the end that such changes may be a matter of public record." 29

The judicial efforts of name assumers to overcome the objections of persons already bearing their names have not always been successful. In a number of cases, decisions have been awarded the objectors on the very grounds suggested in the Falcucci decision.

Since, as the writer has pointed out elsewhere, ${ }^{30}$ it has usually been left to the discretion of each court whether a changer's application will be granted, and thus no single set of standards has come to underlie judicial decisions in these cases, there are bound to be some judges who, though limited by equity and fair dealing, will allow their own personal prejudices to rule their interpretation of the common law prerogatives. Other 
judges, in their attempts to be as honest and objective as Justice Maxey apparently was in Falcucci, may interpret the evidence as presented in the applications and protestation suits, as well as the extenuating circumstances, as suggestive of possible fraud, deliberate or otherwise, or at least unfair and inimical to the interests of the prior name bearers, and thus rule in favor of the latter. Such, the writer feels, may have inspired the rejection by the Toronto court of Justice Honeywell of the petition of the two Stolberg brothers, clothing manufacturers and wholesalers of that city, who sought formally to adopt the name Stollery.

Morris and Israel Stolberg had, for several years, been known in their trade as Stollery, to the inconvenience and embarrassment of the Stollery family of Toronto who were also in the clothing business. Frank Stollery and his sons were the proprietors of several long established enterprises in the city, including the successful Frank Stollery's - a downtown men's clothing store. They sought, in the Stolbergs' bid to formalize their namechange, an opportunity to air their grievance by pointing out that Stollery was a comparatively unique name in North America (borne by only three distantly related families on the whole continent); and, associated as it was with the garment industry, it would only lead to public confusion if a competitor possessed the same name. The Stolbergs argued, however, that there should really be no confusion inasmuch as the two families handled different lines of merchandise, and the Stolbergs' business interests were not and would not be in the Stollery name; their business was, rather, in the firm names of the Service Garment Company and Larry Sportswear.

Judge Honeywell, in rejecting the Stolberg petition, agreed substantially with the objections raised by the Stollerys but pointed out that the common law permitted the petitioners to assume on their own any name they wanted. However, since they had elected to present an application to his court, he preferred to exercise the discretion given him by the then newly amended Ontario Change-of-Name Act to turn down such a request when it appeared that some confusion in identity might occur. ${ }^{31}$ Yet he would gladly consider any request the petitioners might make for a change to some other name.

Similar to the Stolberg case, but one which clearly involved the deliberate effort to "trade upon" the name and reputation of the prior bearer, was the California case ${ }^{32}$ which pitted the late Peter Lorre against one Eugene Weingand, a real estate salesman and aspiring young actor of German birth. Weingand had petitioned a Los Angeles Superior Court to be allowed to change his name to Peter Lorie on the grounds that his own name was hard to pronounce and that he was already known in acting 
circles by his assumed appellation. His request was turned down following appearances by Peter Lorre, the distinguished character actor, as remonstrant, and witnesses in his behalf who told of Weingand's having attempted to pass himself off as Lorre's son to the definite discredit and harm of the older actor. One witness, the manager of an apartment house, testified, that on being informed by the petitioner that he was Peter Lorie, $J r$, and thus naturally assuming that he was Lorre's son, he told Weingand that he had always been an avid fan of his father and asked how he was, having heard that he was not well. "Does he," he asked, "have a liver ailment?" "No," said Weingand, "he has another ailment . . . alcohol." A second apartment house manager recalled that Weingand had once admitted outright that he was Lorre's son; and when she remarked that she didn't know he had a son, Weingand replied that he had only been in this country for a few years.

Remonstrant Lorre and several of his associates then pointed out that, as the actor had appeared in over 150 feature films and countless telecasts and had given other performances in this country in a career spanning some 42 years, he had become known to the American public as an actor of some distinction. If another actor, as Weingand aspired to become, were to use the name Lorie or Lorre, the public would be unable to distinguish between the two, and this might result in artistic damage as well as in some financial loss to the remonstrant.

On Weingand's appeal, the decision of the Superior Court was upheld; Justice (pro tem) Kincaid of the Second District Court of Appeals ruled that the lower court was justified in denying the change for the reasons presented. Kincaid's decision reiterated and supported the remonstrant's contention that Weingand was not a particularly difficult name to pronounce; that the petitioner had no family connection with Lorre, the actor, nor with any other Lorre or Lorie; that since he (Weingand) had a slight physical resemblance to the remonstrant, had deliberately affected his unique mannerisms and speech, and had for at least a year passed himself off to others as, variously, Peter Lorre, Peter Lorie, and Peter Lorie, Jr., as well as the son of Peter Lorre, the actor, he would, indeed, tend to confuse the general public, leading it to be attracted to a performance by the petitioner while expecting to be entertained by the remonstrant, to the definite commercial and professional disadvantage of the latter. In short, it was the view of the appeals court that Weingand had "not acted in good faith" in seeking to assume the name and to "cash in" on the identity and reputation of Peter Lorre, and thus it could not legitimately grant his petition.

One other issue was involved here. The Superior Court's decision had 
included a stipulation that Weingand refrain from ever using the Lorre or Lorie name without the written consent of Peter Lorre, the remonstrant. ${ }^{33}$ Justice Kincaid questioned the propriety of this injunction inasmuch as Sections 1275-1279 of the Code of Civil Procedure do not specifically provide for any such restraints. The court's authority, he said, is limited to the granting of an order either affirming a formal application or denying it. The Superior Court had "exceeded its jurisdiction" in enjoining Weingand from ever using the name Lorie or even Lorre since this he was free to do under the common law, a right given all citizens of California. ${ }^{34}$

\section{Appropriating the Name of Another}

As the writer has attempted to illustrate in this paper, the issue of proprietary right in a surname is one in which basic human feelings and legal precedence do not always coincide. While, according to AngloAmerican common law, both the right of name-change and the freedom of name-choice are generally inalienable, a family whose name may symbolize a heritage of great achievement and respectability may well fear that an assumer of its name might, by his own behavior, cast disparagement upon it and thus upon them. This, as an ethical problem, can hardly be taken lightly. Why, they have asked, should one be allowed to "trade upon" the glory and repute of a person who has made something of his name? And if one is of the same occupation as the person whose name he chooses to assume, it is quite natural to suspect that there may be a deliberate intent to do this.

Though few persons have been so bold as to suggest that the right to change one's name be abrogated, many have felt that such right does not give a parallel right to appropriate the name of another without that other's consent. Those who are ignorant of the law on this matter, like the author of a letter once published in the New York Times, feel that names are like trademarks and thus the property of their bearers. ${ }^{35}$ But the law has clearly maintained that personal names are not trademarks, and one does not have the right to prevent another from using his name so long as there is no evidence of any intent on the other's part thereby to defraud the public or the prior name bearer. ${ }^{36}$

Nevertheless, from time to time, individual judges, at their own discretion and ostensibly in an effort to minimize as much as possible the chance of error or confusion in succession and identity, have seen fit to interpret this position in different ways. Thus, occasional attempts to officially assume the name of another person or family have failed. But nearly always, with few exceptions, one is free to adopt such a name on his own. 
Even in a state like Pennsylvania, which ostensibly prohibits the unrestrained assumption of another name, "there is no penalty unless it (the assumption) is 'for the purpose of avoiding payment of taxes or debts' when there may be a fine at the discretion of the court at not more than $\$ 100$ and costs." 37

Of course, the law is such that it can be changed; and if the feelings of well established family members are strong enough and their influence in legislative bodies powerful enough, bills can be introduced, as they have been on occasion, to restrict the untrammelled practice of name-changing or the source of names which can be adopted. At the very least, as it has often been suggested, a law might be passed to encourage or require the acquisition of consent from the family whose name is sought for adoption. But obviously the question here (and this is the crux of the whole matter) is that, since there is no right of exclusive possession of a name, owing at least in part to the fact that very few if any surnames are not shared by at least two families somewhere in the world, what right does the member of any particular family have to say that someone cannot adopt his name? Why should the consent of a name-bearer be required if that name-bearer has no valid claim to that name?

Perhaps there might be an ethical justification for name ownership if one were to create his own name after he had assured himself that no one else in the world possesses it. But, under the common law, at least, there is no legal basis for his assumption of exclusive right to it. Someone else in some other place, even at the same time, may, by the sheerest of coincidences, create the identical name. Who then can claim ownership of it?

\section{Notes}

'Thomas Falconer, On Surnames and the Rules of Law Affecting Their Change, 2d ed., London, 1862; Falconer, Supplement to an Essay on Surnames, London, 1863.

2J. Manning, "Change of Name," The Athenaeum, no. 1884, Dec. 5, 1863, pp. 759-60.

3I Ibid. Manning quotes Falconer on the advantage in this to famous persons: "If a person who changes his name is of known position, and of admitted good repute and honour, so soon as he publicly announces his change of surname his new name is his legal name."' He has, in other words, an advantage in this matter over others less well known.

45 B. and Ald. 544 (1822).

${ }^{5}$ Lord Eldon's decision as found in Leigh v. Leigh, 15 Ves. 92, 33 E.R. 690, 35 Digest 710, 86 (1808).

6"'The Law of Surnames," The Gentleman's Magazine, vol. 243 (new series, vol. 21), Oct. 1878, pp. 499-500.

7(1465), 5 Edw. IV, cap. 3; Irish Statutes (ed. 1765), I. 29. 
8(1569), 11 Eliz. sess. 2, cap. 1, s.3; Irish Statutes (ed. 1765), I. 335 (Irish Statutes Revised, appendix, p. 772).

${ }^{9}(1600)$, cap. 2; Acts of Scotland, IV. 213.

${ }^{10} \mathrm{By}$ an Order in Council of 1603, ratified in 1617. Cap. 17. Acts of Scotland, IV. 379 (ed. 1770).

"See Anthony Linell, The Law of Names: Public, Private, \& Corporate, London: Butterworth, 1938, pp. 47-50.

${ }^{12}$ In his decision in Cowley v. Cowley (1901), A.C. 450, 70 L.J.P. 83, 85 L.T. 254, 50 W.R. 81, 17 T.L.R. 725, 35 Digest 703, Lord Lindley wrote: "Speaking generally, the law of this country allows any person to assume and use any name, provided its use is not calculated to deceive and to inflict pecuniary loss." This assertion echoes Lord Chelmsford's classic statement in DuBoulay v. DuBoulay (1869), L.R. 2 P.C. 430, 6 Moore P.C.N.S. 31, 38 L.J.P.C. 35, 22 L.T. 228, 17 W.R. 594, 16 E.R. 638, 35 Digest 702: "In this country we do not recognize the absolute right of a person to a particular name to the extent of entitling him to prevent the assumption of that name by a stranger . . . The mere assumption of a name, which is the patronymic of a family, by a stranger who had never before been called by that name, whatever cause of annoyance it may be to the family, is a grievance for which our law affords no redress. "'Manning, referring to the right to adopt the surname of another without his consent, once claimed that, while this was tacitly accepted in that such a right was not disallowed by statute, each case should be largely judged on its own merits. The standing rule at the Herald's College is that such a name be taken only with the consent of the person or family whose name is desired of adoption. Otherwise the problem of identity-confusion would arise; there would be great inconvenience with several persons bearing the identical name living or working in the same place. Manning suggested that, in such an eventuality, convenience dictates that one or the other take another name, a new one unrelated to the one in question; or, preferably, a name unlike any other in existence, a wholly invented name. Op. cit. supra, note 2.

${ }^{13}$ It may be pointed out that Lord Coke's oft-repeated dictum: "And this doth agree with our ancient books, where it is holden that a man may have diverse surnames at diverse times, but not diverse Christian names" (Coke upon Littleton, vol. II, p. 218, 1818, ed. J. H. Thomas) was itself derived almost in toto from William de Herle's statement that "Homme peut a divers temps aver divers nosmes mes nemy per baptisme." (1334, Y.B. 9 Ed. 3, 14, Pl. 18). Linell suggests that this position is "plainly logical: a man could be baptized only once, and therefore could receive only one baptismal name and could never change that name ("unless of course, by Act of Parliament, by which the ordinary rules of law may be overridden') because the historical fact of his having been so baptized can never be abrogated." Op. cit. supra note 11, at pp. 5-6.

${ }^{14}$ City Council v. King, 4 McCord L. 487.

15 "A person has no such exclusive right to the use of a surname . . . as will enable him to prevent its assumption by another. Nor will an injunction issue to restrain the unauthorized use of a person's name, as in a testimonial, even though such use is calculated to injure him in his profession, unless such use is shown to be injurious to the plaintiff's reputation, or to his property." Archibald H. Throckmorton, "Names" Cyclopedia of Law and Procedure, vol. 29, 1908, p. 271. Precedents cited: Olin v. Bate, 98 Ill. 53; 38 Am. Rep. 278; DuBoulay v. DuBoulay, L.R. 2 P.C. 430; Dockrell v. Dougall, 78 L.T. Rep. N.S. 840.

${ }^{16}$ G.S. Arnold, Personal Names, 15 Yale L.J. 227 (1906).

${ }^{17}$ Minor Bronaugh, “Names," Law Notes (Northport), vol. 33, Aug. 1929, pp. 85-89.

${ }^{18}$ Goldwyn Pictures Corp. v. Goldwyn, 296 Fed. 391 (1924).

19I is suspected that Goldfish, itself, was a derived name; that actually Goldwyn's name had originally been Gelbfisch (or Gelbfish) but that, on his arrival in this country at the age of 11, his name was changed at the convenience of an impatient immigration official.

${ }^{20}$ Robert M. Rennick, "Judicial Procedures for a Change of Name in the United States," Names, vol. 13(3), Sept. 1965, pp. 145-68.

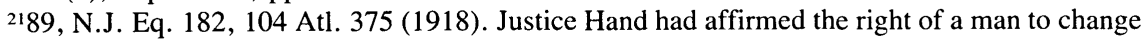
his name and to continue to carry on his economic affairs with it: "There seems to be no authority for the proposition that a man may not contract to give up his own name in business. . . One may 
continue to practice one's calling under another name, at least as regards the public. . . ." Justice Hand also knew of no legal basis for any "supposition that a surname is entitled to less protection if assumed than if familial. . . . Of course, . . . a name assumed for the purpose of trading on another's good-will would be absolutely enjoined. And, therefore, if there were any suspicion that the defendant had adopted his name . . . because he contemplated using it as he now proposes, he could be enjoined. This would be true, because it would then be apparent that he had no interest in the name to protect other than its use to take away the plaintiff's customers. There is, however, no ground for any such suspicion. . . . He had no thought of its [his name's] competitive use [when he adopted it.]"

Applicable here, though not to the writer's knowledge having been employed as precedents for the Goldwyn decisions, was the ruling in Meneely v. Meneely, 62 N.Y. 427 (1875), that: "a person cannot make a trade mark of his own name and thus debar others, having the same name, from using it in their business" and "every man has an absolute right to use his own name in his own business, even though he may thereby interfere with and injure the business of another bearing the same name; provided he does not resort to any artifice, or do any act calculated to mislead the public as to the identity of the establishments, and to produce injury to the other beyond that which results from the similarity of the names."

2298 Ill. 53, 38 Am. Rep. 278 (1881).

${ }^{23}$ Some forty years later, this point was to be made explicit in Pfaudler v. Pfaudler Co., 114 Misc. 477,186 N.Y.S: 725 (1920), to the effect that, if persons had proprietary rights to their surnames, anybody with a really common name like Smith or Jones could claim damages from others bearing the same name.

24250 N.Y. 382, 165 N.E. 819 (1929).

${ }^{25}$ Baumann and his "second" wife were co-defendants.

${ }^{26}$ See Rennick, op . cit. supra note 20, at pp. 164-165. Soon after this article appeared, the writer received a letter from a friend of Thomas Frame advising him that the Philadelphia attorney had seen the article and was quite critical of the author's treatment of the Falcucci name case, $355 \mathrm{~Pa}$. 588, 50 A.2d 200 (1947), particularly the fact that he had omitted mention of what Frame considered his major objection to the name adoption. "Not only was the name Frame involved," the attorney pointed out, "but for no reason ever appearing on record, the petitioner, Benjamin, changed his first name to Thomas. That was the crux of the case, but I was never able to get the lower or appellate courts to face up to that objection." The author regrets this inadvertent omission and wishes to make up for it by the more complete discussion of the case which appears in the present article. He also seeks to clarify the provocative "discrete seven years delay" by quoting Frame's statement to his friend that "objections to the original petitions were timely filed but final disposition of the appeals was postponed due to absence in the military service." He was "most eager to argue the appeals" himself.

${ }^{27} 16$ Eng. Rep. 638 (1869)

${ }^{28}$ A similar case was Canada's classic Rezek v. Rennie (Ontario Weekly Notes, Nov. 13, 1946, p. 21) in which the attempt by a Toronto merchant of Czech descent, one Jaroslav Rezek, to take the name Gerald Rennie was blocked by the Rennie Seed family. The Rennies' objection was dismissed on the grounds that, since there were already 150 Rennies listed in the Toronto city directory, another would hardly be likely to cause confusion in identity, especially since Rezek was not "in the seed business."

${ }^{29}$ In re Useldinger, 35 Cal. App. 2d 723, 96 P. 2d 958 (1939).

${ }^{30}$ Rennick, op. cit. supra, note 20, at pp. 153-54.

${ }^{31}$ The Ontario Change-of-Name Act was quite explicit that, "where the judge is of the opinion that the name the applicant seeks . . . is the same . . . or resembles [that] of another person to such an extent that the change ... might reasonably cause mistake or confusion or be a cause of embarrassment or inconvenience to such person, or [if it] . . . is sought for any improper purpose . . . he shall refuse the application."' Section 16:1, Chap. 49 of Revised Statutes of Ontario, 1960, pp. 469-77.

${ }^{32}$ In the Matter of Eugene Weingand, For Change of Name, 41 Cal. Rptr. 778 (1964). 
${ }^{33}$. . . or his estate since the actor had passed away after the presentation of the petition before the Superior Court and before the appeal to the higher court. The remonstrant's widow, Annemarie Lorre, who had been appointed administratrix of his estate, was duly authorized to appear in his place as remonstrant in the appeal proceedings.

${ }^{34}$ In re Ross, 8 Cal. 2d 608, 67 P. 2d 94 (1936).

35 "I agree . . . that persons should have the right to change their names. This, however, should not give such a person the liberty of appropriating . . . the name of another without such owner's consent. Names, after all, are much like trademarks. The law gives one the right to use any trademark provided the trademark chosen is not the property of someone else. The law prevents persons from using a trademark which is so similar to another that it may confuse the general public. This should be the rule concerning the assumption of a new name. The appropriation of well-known or distinguished names is to be condemned. It must be remembered that one or more persons have done some exceptional deeds to make the name known and respected. Their descendants have perhaps done as much in trying to maintain the family name high. To permit anyone to appropriate such a name . . . is in reality taking credit where no credit is due. . . " A.D. Sioris of New York City in New York Times, Sept. 21, 1948, p. 26.

${ }^{36}$ Manning once pointed out that even the issue of fraudulent intent may not always prevent one from successfully assuming the name of another. In Rex v. Burton-upon-Trent ( 2 M \& S 537), it was decided that the name an army deserter had deliberately assumed to avoid detection, by which name alone he was known in the place of his concealment and by which name he was married, had become his true name, and his marriage was legal only in that name. Manning, op. cit. supra note 2 , at pp. 717-18.

${ }^{37}$ Letter to author from Symington P. Landreth, attorney, Philadelphia, Pa., Feb. 1, 1966. 